\title{
Giant Intracranial Xanthoma with Cloudy Vision as the First Symptom: A Case Report and Literature Review
}

This article was published in the following Dove Press journal: International Journal of General Medicine

\author{
Xueting Wang ${ }^{1,2}$ \\ Xuejiao $\mathrm{Li}^{2}$ \\ XuHui $\mathrm{Liu}^{3}$ \\ Yizhe Yin ${ }^{\prime}$ \\ Yalong Dang ${ }^{2}$ \\ Fang Lei ${ }^{\prime}$ \\ 'Department of Ophthalmology, Henan \\ University of Science and Technology \\ School of Medicine, Luoyang, Henan, \\ 47I000, People's Republic of China; \\ ${ }^{2}$ Sanmenxia Central Hospital, Henan \\ University of Science and Technology, \\ Sanmenxia, Henan, 472000, People's \\ Republic of China; ${ }^{3}$ Department of \\ Ophthalmology, The First Affiliated \\ Hospital of Zhengzhou University, \\ Zhengzhou, Henan, 45000I, People's \\ Republic of China
}

\begin{abstract}
A 31-year-old male with mild dizziness complained of cloudy vision in his right eye for 5 days. The visual acuity of both eyes was normal, while the visual contrast sensitivity of both eyes slightly reduced. Fundus examination showed the swollen and radial superficial hemorrhage of his both optic nerves. Brain MRI scan indicated a huge tumor in the right temporal lobe with clear boundary, close to the skull. The midline structure shifted to the left. Blood tests indicated no hyperlipidemia or lipid disorders. The patient then received tumor resection. The size of the tumor was $5.6 \mathrm{~cm} \times 7.5 \mathrm{~cm} \times 10.1 \mathrm{~cm}$. Histology suggested many foam cell accumulations and the tumor was positive for CD34, CD99, Vimentin, $\beta$-Catenin and CD68, but negative for EMA, GFAP, IDH-1, Oliga-2, PR, S-100, and CD1a. Three months after surgery, MRI showed the midline structure was back to normal. The swollen and radial superficial hemorrhage of optic nerves had disappeared. The visual acuity and visual field remained normal.
\end{abstract}

Keywords: intracranial xanthoma, optic nerve, visual function, neurological disorder, optic disc edema

A 31-year-old male complained of blurred vision in his right eye for five days, accompanied by mild dizziness. The visual acuity of both eyes was 20/20. The visual contrast sensitivity of both eyes reduced slightly. No yellowish nude in the eyelid and elsewhere. No obvious abnormalities in the conjunctiva, cornea, anterior chamber, iris, or lens of either eye. The pupil size of both eyes was $2.5 \mathrm{~mm}$, RAPD (-). Fundus examination showed the swollen and radial superficial hemorrhage of his both optic nerves. (Figure $1 \mathrm{~A}$ and B). Blood examination showed the total cholesterol, triglycerides, high density lipoprotein and low-density lipoprotein were within the normal limits. Brain MRI showed a huge mass in the right temporal lobe, clear boundary, and multiple separations. The right temporal lobe and lateral ventricle were compressed, the midline structure shifted to the left. The lesion site showed low signal intensity on T1-weighted images (Figure 2A) and high signal intensity on T2-weighted images (Figure 2B). Contrastenhanced T1-weighted images showed strong enhancement at the boundary (Figure 2C and D). The patient then received tumor resection. During the operation, we found the skull around the tumor area was partially protruding; the tumor had invaded the skull; the adhesion of tumor and skull was tight. The size of the tumor was about $5.6 \mathrm{~cm} \times 7.5 \mathrm{~cm} \times$ $10.1 \mathrm{~cm}$, and the texture was soft and gelatinous (Figure 3). Histology showed a large number of foam cell accumulation (Figure 4). The immunohistochemistry was as
Correspondence: Yalong Dang; Fang Lei Tel +86-398-3II8I49;

+86-379-6423I886

Email dangyalong@haust.edu.cn;

leifang@haust.edu.cn
International Journal of General Medicine 2021:14 II0I-I I05

$\mid \mathbf{I 0 |}$

DovePress $f$ in $\boldsymbol{V}$

http://doiorg/10.2147/1GM.S290893 (c) (i) (5) 2021 Wang et al. This work is published and licensed by Dove Medical Press Limited. The full terms of this license are available at https:///www.dovepress.com/terms. cc) Php and incorporate the Creative Commons Attribution - Non Commercial (unported, v3.0) License (http:///creativecommons.org/licenses/by-nc/3.0/). By accessing the work you hereby accept the Terms. Non-commercial uses of the work are permitted without any further permission from Dove Medical Press Limited, provided the work is properly attributed. For permission for commercial use of this work, please see paragraphs 4.2 and 5 of our Terms (https://www.dovepress.com/terms.php). 


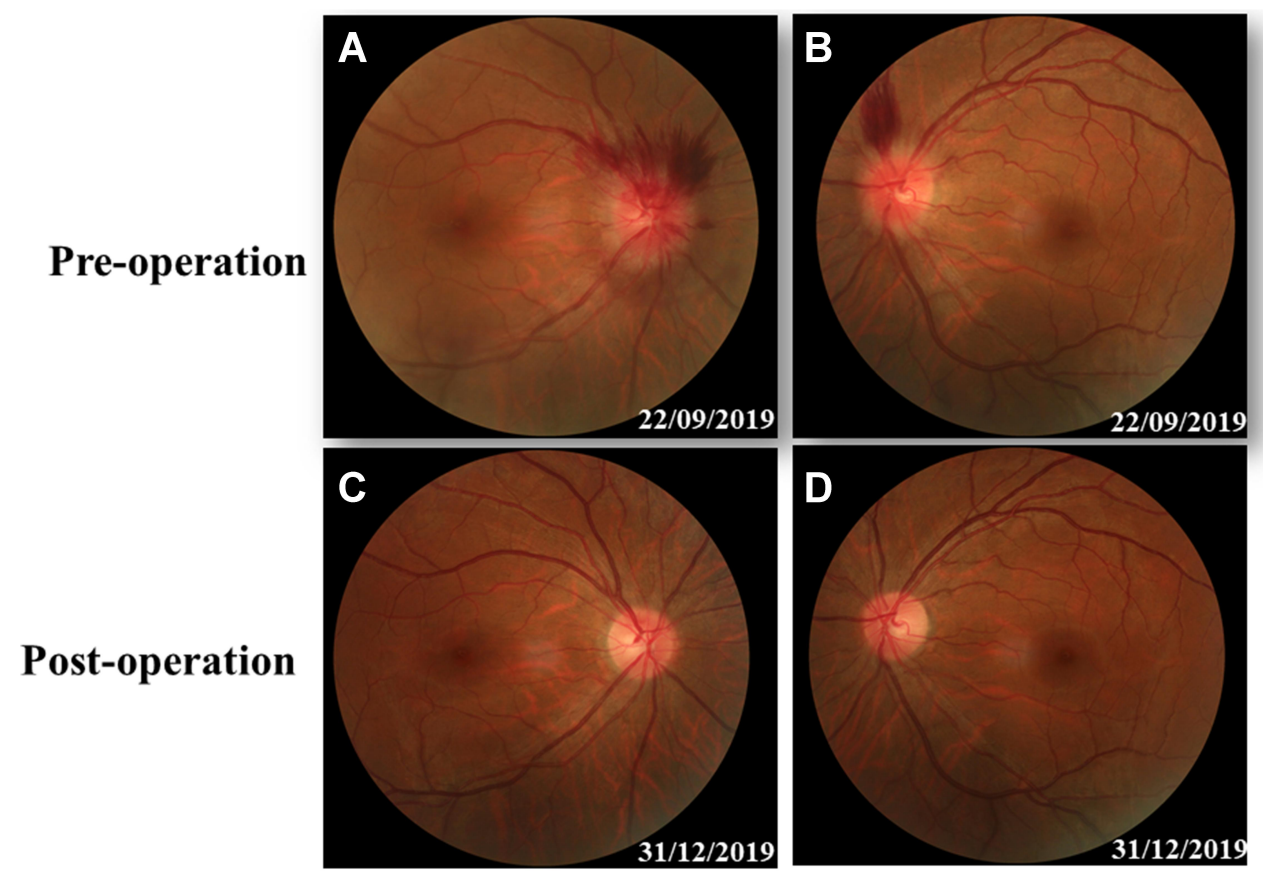

Figure I Fundus photography. The swelling and blurry boundaries of both optic nerves were present (A and $\mathbf{B})$. There was a splinter radial superficial retinal hemorrhage above the optic disc; no other obvious abnormality was observed ( $\mathbf{A}$ and $\mathbf{B}$ ). Three months after surgery, all these symptoms, including optic nerve swelling and retinal hemorrhage disappeared (C and $\mathbf{D})$.
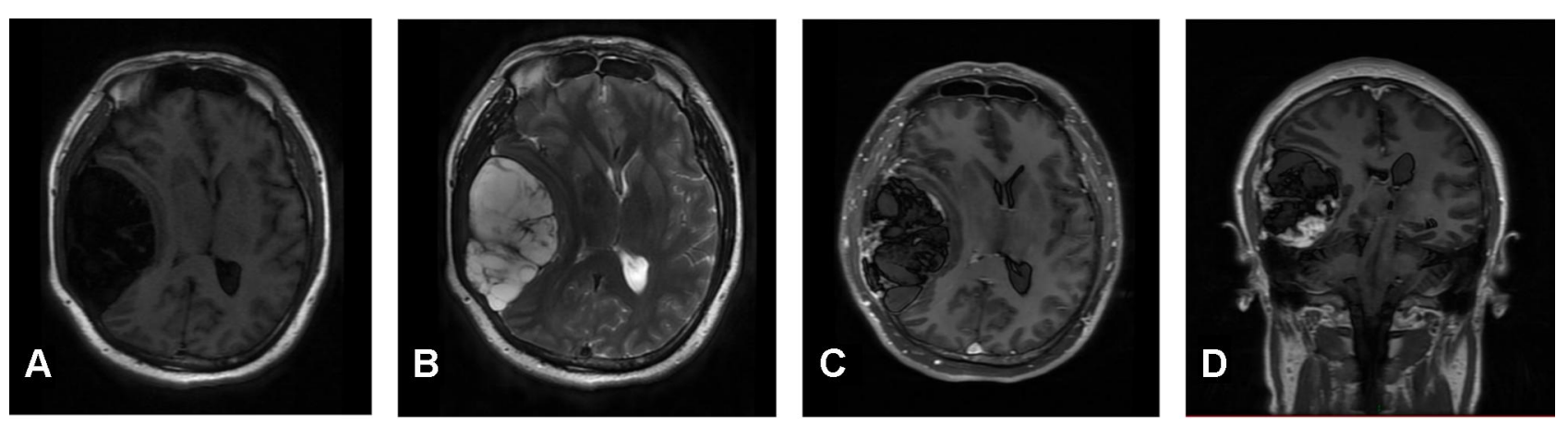

Figure 2 Brain MRI before surgery. Brain MRI showed a huge mass in the right temporal lobe, clear boundary, and multiple separations. The right temporal lobe and lateral ventricle were compressed, the midline structure shifted to the left (A and $\mathbf{B})$. The lesion site showed low signal intensity on TI-weighted images (A) and high signal intensity on T2-weighted images (B). Contrast-enhanced TI-weighted images showed strong enhancement at the boundary (C and D).

follows: CD34 (+), CD99 (+), Vim (+), CD68 (+), $\beta$-Catenin $(+)$, EMA (-), GFAP $(-)$, IDH-1 (-), Oliga-2 (-), PR (-), S-100 (-), CD1a (-), Ki-67 index was about $10 \%$. Three months follow up showed the visual acuity and visual fields remained normal. The optic disc edema and hemorrhages had disappeared (Figure 1C and D). T1-weighted (Figure 5A) and T2-weighted (Figure 5B) images show the midline structure returned to normal. A mild edema of temporoparietal was observed (Figure 5A and B). Contrast-enhanced T1weighted images (Figure 5C and D) show no sign of recurrence.
Written informed consent was obtained from the patient for the publication of the case details and images. No institutional review board approval was required for the publication of the case report.

\section{Discussion}

Xanthomas are produced by the accumulation of foam cells which originate from the oxidation of macrophages overloaded with low-density lipoprotein particles. Generally, Xanthomas can be divided into three types: both hyperlipidemia xanthoma ${ }^{1}$ and non-hyperlipidemia xanthomas $^{2}$ contain lipids and collagen, whereas 


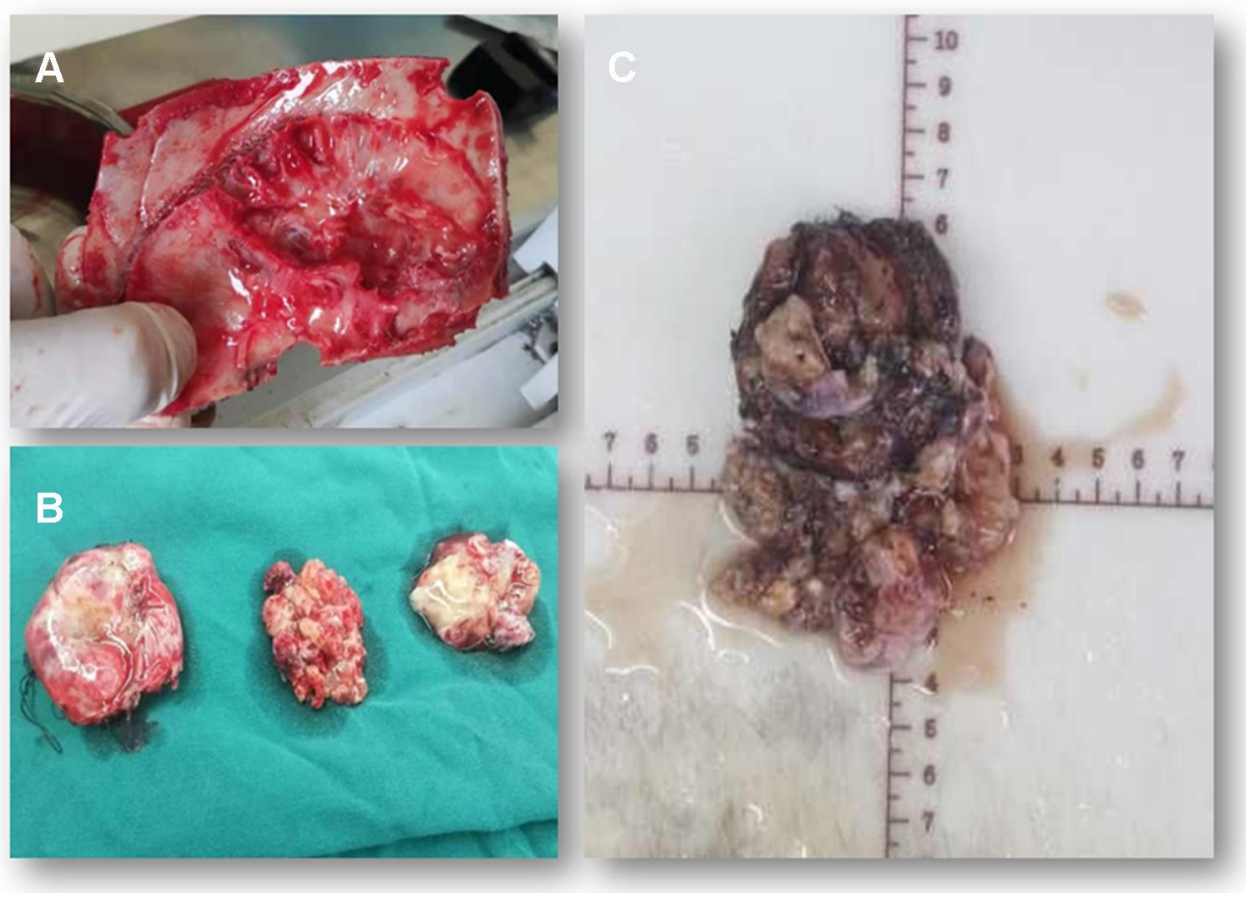

Figure 3 Surgical observations. The skull in the tumor area was partially protruding, the tumor invaded the skull, the adhesion of tumor tissue and skull was tight and the brain tissue of the right temporal lobe was compressed $(\mathbf{A})$. The actual size of the tumor was $5.6 \times 7.5 \times 10.1 \mathrm{~cm}$, and the texture was soft and gelatinous $(\mathbf{B}$ and $\mathbf{C})$.
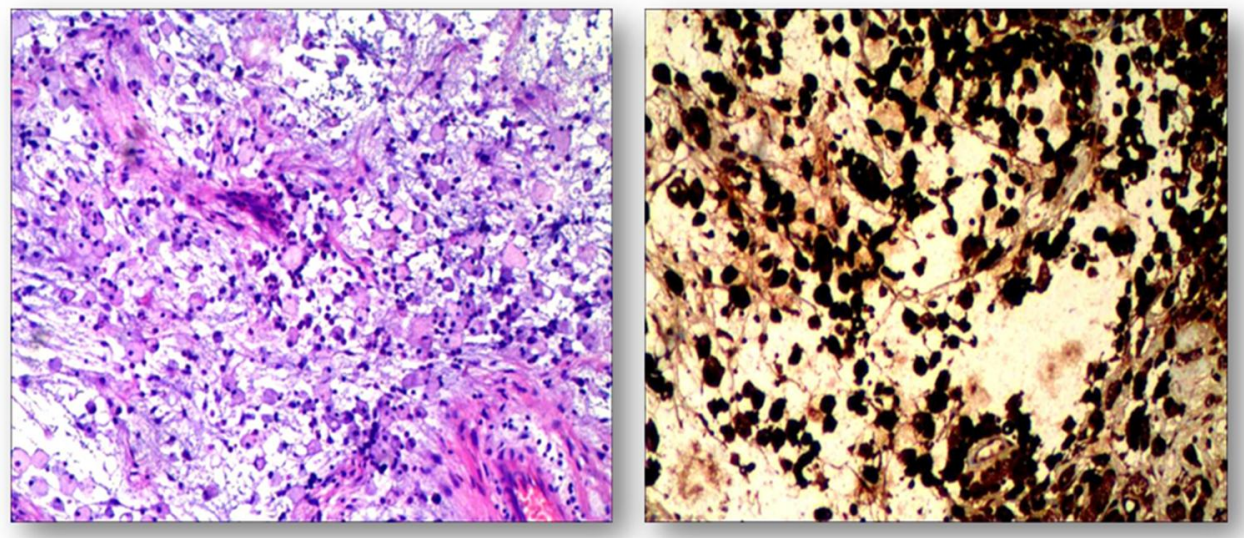

Figure 4 Hematoxylin and eosin staining. Foam cell accumulation in the mucous connective tissue of the right temporal lobe.

progressive collagen necrosis, cholesterol crystal fissures and lipid vacuoles can be seen in the tissue examination of necrobiotic xanthogranuloma. ${ }^{3,4}$ Xanthomas have a variety of clinical manifestations, depending on the location of lesions. The most common cases show yellowish collection of cholesterol underneath the skin, usually on or around the eyelids. ${ }^{5}$ Although intracranial xanthoma is not a rare condition, ${ }^{6-9}$ the huge size of tumor without hyperlipidemia or lipid disorders has never been reported.

Xanthomas are associated with a variety of diseases, especially lipid-storage and metabolism disorders, which often occur in patients with type II hyperlipidemia. Since its mechanism is similar to that of early atherosclerosis, xanthoma has received more attention in recent years. A prospective study, which followed nearly 13,000 subjects for more than 20 years, found that, even after adjusting for covariables such as age, gender, diabetes, smoking, hypolipidemic therapy and postmenopausal status, the occurrence of xanthoma was associated with: a significant increase in the risk of myocardial infarction ( $48 \%$ increase); ischemic heart disease $(38 \%$ increase); and lower-extremity ischemic disease $\left(70 \%\right.$ increase) ${ }^{10}$ 

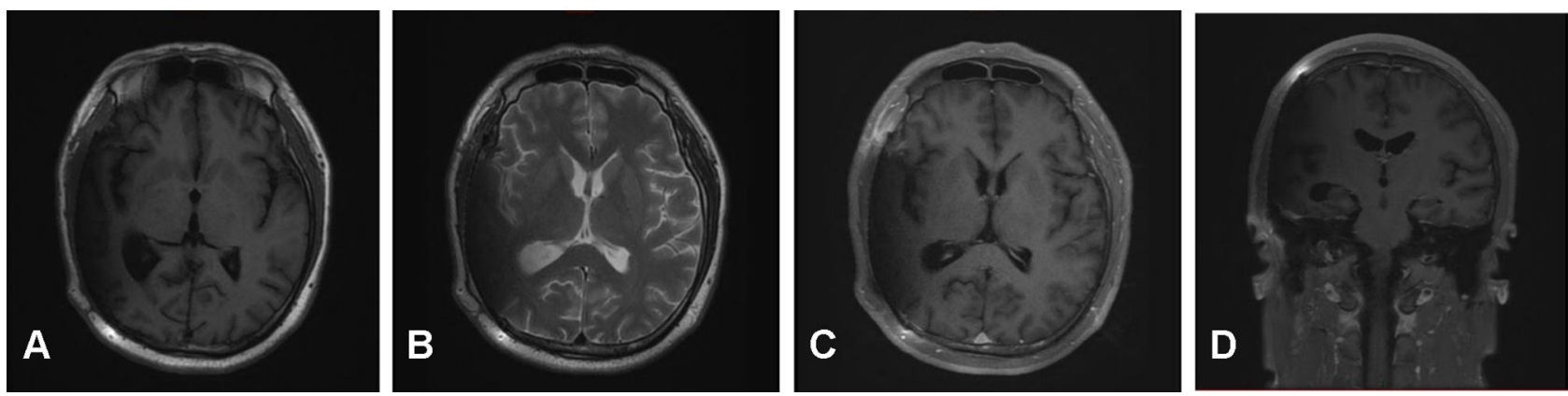

Figure 5 Three-month follow-up (MRI). TI-weighted and T2-weighted images show the midline structure returned to normal. A mild edema of temporoparietal was observed (A and $\mathbf{B})$. Contrast-enhanced TI-weighted images ( $\mathbf{C}$ and $\mathbf{D})$ show no sign of recurrence.

To-date, most of the reported intracranial xanthomas have been characterized by hyperlipidemia, especially type II hyperlipidemia. There was also a report of a young patient with bilateral disc swelling caused by intracranial xanthoma. But, the patient had severe hyperlipidemia, and the patient's mother and two sons had elevated blood lipids. ${ }^{11}$ However, hyperlipidemia or lipid disorder was not found in this case.

The diagnosis and differential diagnosis of intracranial xanthoma majorly rely on histology and immunohistochemistry findings. No accurate diagnosis can be determined until operation. The giant foam cells drive from macrophages but not from smooth muscle cells, neural cells or the transformation of epithelial cells. ${ }^{12}$ Thus, in this case, the tumor was positive for CD68 and Vimentin, commonly used macrophage markers ${ }^{13,14}$ and CD99 which plays a key role in the migration of macrophages through endothelial junctions ${ }^{15}$ and $\beta$-Catenin which regulates macrophage activation. ${ }^{16}$ In contrast, this tumor was negative for makers of neural origin: S-100, ${ }^{17}$ GFAP, ${ }^{18}$ Oliga- $2^{19}$ and IDH-.$-^{20}$ Also, since xanthomas are apparently not true neoplasms, ${ }^{21}$ it is negative for $\mathrm{PR}^{22}$ and CD1a. $^{23}$

Because the incidence of intracranial xanthoma is low, no systematic study shows the recurrence rate and prevention for this disease. Theoretically, reducing blood triglyceride and cholesterol levels might be beneficial for this tumor. ${ }^{24}$ Long term, large number observation study might be needed.

\section{Acknowledgments}

The authors thank Claire Barnes, $\mathrm{PhD}$, from Liwen Bianji, Edanz Editing China, for editing the English text of a draft of this manuscript. This study was supported by the key
R\&D and Promotion Projects of Henan Province No. 182102410099 and No.182102310452.

\section{Disclosure}

The authors report no conflicts of interest in this work.

\section{References}

1. Zaremba J, Zaczkiewicz A, Placek W. Eruptive xanthomas. Postepy Dermatol Alergol. 2013;30:399-402. doi:10.5114/pdia.2013.39439

2. Wang Z, Lin Z-W, Huang -L-L, et al. Primary non-hyperlipidemia xanthoma of bone: a case report with review of the literature. Int J Clin Exp Med. 2014;7:4503-4508.

3. Kim YS, Ju HJ, Park CJ, Lee KH. A Case of Cholesterol Granuloma Presenting as a Cutaneous Nodule. Ann Dermatol. 2017;29:383-384. doi:10.5021/ad.2017.29.3.383

4. De la Torre C, Losada A, Cruces MJ. Necrobiosis lipoidica: a case with prominent cholesterol clefting and transepithelial elimination. Am J Dermatopathol. 1999;21:575-577. doi:10.1097/00000372199912000-00014

5. Singh AP, Sikarwar S, Jatav OP, Saify K. Normolipemic tuberous xanthomas. Indian J Dermatol. 2009;54:176-179. doi:10.4103/00195154.53190

6. Algoed L, Caemaert J, Achten E, van Aken J, de Reuck J. A large intracranial xanthoma in familial hypercholesterolemia. Clin Neurol Neurosurg. 1994;96:79-82. doi:10.1016/0303-8467(94)90034-5

7. Yang G-Z, Li J, Wang L-P. Disseminated intracranial xanthoma disseminatum: a rare case report and review of literature. Diagn Pathol. 2016;11:78. doi:10.1186/s13000-016-0531-1

8. Bonhomme GR, Loevner LA, Yen DM, Deems DA, Bigelow DC, Mirza N. Extensive intracranial xanthoma associated with type II hyperlipidemia. AJNR Am J Neuroradiol. 2000;21:353-355.

9. Hwang YJ, Hur G, Cha SJ, Kim YH, Kim SY, Kim MK. Intracranial xanthoma: long-term follow-up MR findings. AJNR Am J Neuroradiol. 2006;27:423-426.

10. Christoffersen M, Frikke-Schmidt R, Schnohr P, Jensen GB, Nordestgaard BG, Tybjærg-Hansen A. Xanthelasmata, arcus corneae, and ischaemic vascular disease and death in general population: prospective cohort study. BMJ. 2011;343:d5497. doi:10.1136/bmj. d5497

11. Rees A, Lee G, Stocks J, Vella MA, Katz J, Galton DJ. Raised intracranial pressure due to large intracranial xanthoma. $\mathrm{Br}$ Med J. 1984;288:1722-1723. doi:10.1136/bmj.288.6432.1722

12. Braun-Falco O. Origin, structure, and function of the xanthoma cell. Nutr Metab. 1973;15:68-88. doi:10.1159/000175424 
13. Holness CL, Simmons DL. Molecular cloning of CD68, a human macrophage marker related to lysosomal glycoproteins. Blood. 1993;81:1607-1613. doi:10.1182/blood.V81.6.1607.1607

14. Benes P, Macecková V, Zdráhal Z, et al. Role of vimentin in regulation of monocyte/macrophage differentiation. Differentiation. 2006;74:265-276. doi:10.1111/j.1432-0436.2006.00077.x

15. Schenkel AR, Mamdouh Z, Chen X, Liebman RM, Muller WA. CD99 plays a major role in the migration of monocytes through endothelial junctions. Nat Immunol. 2002;3:143-150. doi:10.1038/ ni749

16. Feng Y, Ren J, Gui Y, et al. Wnt/ $\beta$-Catenin-Promoted Macrophage Alternative Activation Contributes to Kidney Fibrosis. J Am Soc Nephrol. 2018;29:182-193. doi:10.1681/ASN.2017040391

17. Cochran AJ, Wen DR. S-100 protein as a marker for melanocytic and other tumours. Pathology. 1985;17:340-345. doi:10.3109/ 00313028509063777

18. Wislet-Gendebien S, Leprince P, Moonen G, Rogister B. Regulation of neural markers nestin and GFAP expression by cultivated bone marrow stromal cells. J Cell Sci. 2003;116:3295-3302. doi:10.1242/ jes.00639
19. Gaber ZB, Novitch BG. All the Embryo's a Stage, and Olig2 in Its Time Plays Many Parts. Neuron. 2011;69:833-835. doi:10.1016/j. neuron.2011.02.037

20. Rosiak K, Smolarz M, Stec WJ, et al. IDH1R132H in Neural Stem Cells: differentiation Impaired by Increased Apoptosis. PLoS One. 2016;11:e0154726. doi:10.1371/journal.pone.0154726

21. Haagensen CD. Xanthoma of the Breast. Am J Cancer. 1932;16:1077-1103.

22. Kabel AM. Tumor markers of breast cancer: new prospectives. J Oncol Sci. 2017;3:5-11. doi:10.1016/j.jons.2017.01.001

23. Coventry B, Heinzel S. CD1a in human cancers: a new role for an old molecule. Trends Immunol. 2004;25:242-248. doi:10.1016/j. it.2004.03.002

24. Bell A, Shreenath AP. Xanthoma. Treasure Island, FL: StatPearls Publishing; 2020.
International Journal of General Medicine

\section{Publish your work in this journal}

The International Journal of General Medicine is an international, peer-reviewed open-access journal that focuses on general and internal medicine, pathogenesis, epidemiology, diagnosis, monitoring and treatment protocols. The journal is characterized by the rapid reporting of reviews, original research and clinical studies
Dovepress

across all disease areas. The manuscript management system is completely online and includes a very quick and fair peer-review system, which is all easy to use. Visit http://www.dovepress.com/ testimonials.php to read real quotes from published authors.

Submit your manuscript here: https://www.dovepress.com/international-journal-of-general-medicine-journal 